\title{
Jarvis Island
}

National Cancer Institute

\section{Source}

National Cancer Institute. Jarvis Island. NCI Thesaurus. Code C123761.

An island in the South Pacific Ocean between Hawaii and the Marshall Islands. 